\title{
Article \\ Effects of Leachate Fertigation and the Addition of Hydrogen Peroxide on Growth and Nutrient Balance in Dracaena deremensis Potted Plants
}

\author{
Pedro García-Caparrós ${ }^{1,+}{ }^{\text {, }}$ Cristina Velasquez Espino ${ }^{2}$ and María Teresa Lao ${ }^{1, *,+(\mathbb{D})}$ \\ 1 Agronomy Department of Superior School Engineering, University of Almeria, CIAIMBITAL, \\ Agrifood Campus of International Excellence ceiA3, Ctra. Sacramento s/n, La Cañada de San Urbano, \\ 04120 Almería, Spain; pedrogar123@hotmail.com \\ 2 Facultad de Ciencias Agrotecnológicas, Universidad Autónoma de Chihuahua, 31034 Chihuahua, Mexico; \\ civez94@hotmail.com \\ * Correspondence: mtlao@ual.es; Tel.: +34-950-015876; Fax: +34-950-015939 \\ + Both authors contributed equally to this work.
}

check for updates

Citation: García-Caparrós, P.; Velasquez Espino, C.; Lao, M.T. Effects of Leachate Fertigation and the Addition of Hydrogen Peroxide on Growth and Nutrient Balance in Dracaena deremensis Potted Plants.

Agronomy 2021, 11, 127.

https:/ / doi.org/10.3390/agronomy 11010127

Received: 4 December 2020

Accepted: 8 January 2021

Published: 11 January 2021

Publisher's Note: MDPI stays neutral with regard to jurisdictional clai$\mathrm{ms}$ in published maps and institutional affiliations.

Copyright: $\odot 2021$ by the authors. Licensee MDPI, Basel, Switzerland. This article is an open access article distributed under the terms and conditions of the Creative Commons Attribution (CC BY) license (https:// creativecommons.org/licenses/by/ $4.0 /)$.
Abstract: The reuse of drainages for cultivating more salt tolerant crops can be a useful tool especially in arid regions, where there are severe problems for crops water management. Dracaena deremensis L. plants were cultured in pots with sphagnum peat-moss and were subjected to three fertigation treatments for 8 weeks: control treatment or standard nutrient solution $\left(D_{0}\right)$, raw leachates from Chrysalidocarpus lutescens $\mathrm{H}$. Wendl plants $\left(\mathrm{D}_{\mathrm{L}}\right)$ and the same leachate blending with $\mathrm{H}_{2} \mathrm{O}_{2}(1.2 \mathrm{M})$ at $1 \%(v / v)\left(\mathrm{D}_{\mathrm{L}}+\mathrm{H}_{2} \mathrm{O}_{2}\right)$. After harvesting, ornamental and biomass parameters, leaf and root proline and total soluble sugar concentration and nutrient balance were assessed in each fertigation treatment. Plant height, leaf and total dry weight had the highest values in plants fertigated with leachates with $\mathrm{H}_{2} \mathrm{O}_{2}$, whereas root length, leaf number, $\mathrm{RGB}$ values and pigment concentration declined significantly in plants fertigated with leachates from $C$. lutescens with or without $\mathrm{H}_{2} \mathrm{O}_{2}$. The fertigation with leachates, regardless of the presence or absence of $\mathrm{H}_{2} \mathrm{O}_{2}$ increased root and leaf proline concentration. Nevertheless, root and leaf total soluble sugar concentration did not show a clear trend under the treatments assessed. Regarding nutrient balance, the addition of $\mathrm{H}_{2} \mathrm{O}_{2}$ in the leachate resulted in an increase in plant nutrient uptake and efficiency compared to the control treatment. The fertigation with leachates with or without $\mathrm{H}_{2} \mathrm{O}_{2}$ increased nitrogen and potassium leached per plant compared to plants fertigated with the standard nutrient solution. The reuse of drainages is a viable option to produce ornamental plants reducing the problematic associated with the water consumption and the release of nutrients into the environment.

Keywords: biomass; cascade cropping system; proline; total soluble sugars; ornamental; oxygation

\section{Introduction}

Nowadays, the production of potted plants is an important economic source in the horticultural industry. They are appreciated worldwide for gardening and landscaping projects [1]. It is estimated that the ornamental plant sector generates around 300 billion USD [2]. There is a high demand for ornamental plants due to the urban expansion and attention to plant functions and aesthetical advantages [3].

The production of containerized ornamental plants has some drawbacks since it requires a frequently fertigation due to the confinement of roots in a limited volume in a substrate with low capacity of water and nutrient retention resulting in the pollution of ground and surface water [4]. Although the leachates generated by these plants are usually rich in nutrients, they also contain a high concentration of $\mathrm{Na}$ and $\mathrm{Cl}$ which can be excessive for the non-salt tolerant cultures [5].

Under these adverse conditions generated by the excessive leachate, the implementation of a Serial Biological Concentration (SBC) or cascade cropping system could be an 
environmentally sustainable option. The cascade cropping system is based on the collection of the leachate from beneath one crop to be used for the irrigation of the consequent more salt tolerant crop in the series with the main aim of reducing almost entirely the leachate volume from the last crop [6].

Oxygation is a technology based on the increase in $\mathrm{O}_{2}$ concentration in the root zone and can be achieved through mixing air or chemical compounds such as hydrogen peroxide $\left(\mathrm{H}_{2} \mathrm{O}_{2}\right)$ with irrigation water before to be distributed in the irrigation lines [7]. Hydrogen peroxide was used many years ago in agriculture for seed sterilization [8] and currently can be used for cleaning drippers or controlling pests [9]. Besides the effects already mentioned, a higher level of oxygation in the root zone due to the application of $\mathrm{H}_{2} \mathrm{O}_{2}$ in the irrigation water and the consequent enhancement of crop growth has been reported by several researchers $[10,11]$. Moreover, the exogenous application of $\mathrm{H}_{2} \mathrm{O}_{2}$ has been reported as ameliorative in the damage caused by saline conditions in several crops [12,13].

Dracaena deremensis is a foliage plant of high importance belonging to the family Agavaceae. Leaf color ranges from green to grey-green with various white striped patterns available. This species is well valued as interiorscapes because of its attractive form, color, and durability [14].

We have already investigated the potential use of a cascade cropping system with horticultural and ornamental plants to achieve the concomitant production of several species with water and nutrient savings $[15,16]$. Although the results were positive with improved yields and water and nutrient savings, the following step was to include some chemical compound in the leachate generated by the cascade cropping system in order to ameliorate the damages caused by salt accumulation in the substrate. Therefore, in this work, a pot experiment with $D$. deremensis was conducted to test how the reuse of the leachates from Chrysalidocarpus lutescens plants and the addition of hydrogen peroxide in the leachate affects biomass, pigment concentration, biochemical parameters, and water and nutrient uptake efficiencies and their losses.

\section{Materials and Methods}

\subsection{Experimental Site and Growing Conditions}

Seedlings of Dracaena deremensis plants (height: $30.1 \mathrm{~cm}$, and plant dry weight: $6.5 \mathrm{~g}$ ) were transferred to plastic containers with a volume of $1.5 \mathrm{~L}$. The substrate used in the experiment was sphagnum peat-moss. The experiment was carried out over 8 weeks in a plastic greenhouse in the University of Almeria $\left(36^{\circ} 49^{\prime} \mathrm{N}, 2^{\circ} 24^{\prime} \mathrm{W}\right)$. During the experimental period, the climatic conditions were recorded with HOBO SHUTTLE sensors (model H08-004-02). The average temperature was $16.5 \pm 1.5^{\circ} \mathrm{C}$, relative humidity $(\mathrm{RH})$ was $55.6 \pm 2.9 \%$, and photosynthetically active radiation (PAR) was $55.4 \pm 4.4 \mu \mathrm{mol} \mathrm{m}^{-2} \mathrm{~s}^{-1}$. The experiment consisted of the irrigation of Dracaena deremensis plants with three different fertigation treatments: standard nutrient solution or control treatment $\left(\mathrm{D}_{0}\right)$ proposed by Jiménez and Caballero [17] adapted for the culture of ornamental plants under Mediterranean conditions and two sequential reuse treatments: one of them was composed of raw leachates from Chrysalidocarpus lutescens plants $\left(\mathrm{D}_{\mathrm{L}}\right)$ and the other was the same leachate blending with $\mathrm{H}_{2} \mathrm{O}_{2}(1.2 \mathrm{M})$ at $1 \%(v / v)\left(\mathrm{D}_{\mathrm{L}}+\mathrm{H}_{2} \mathrm{O}_{2}\right)$ (Figure 1). The plants were manually fertigated using a test tube and the same volume of $30 \mathrm{~mL}(2 \%$ of the volume container) was added to each container every day, resulting in $1.7 \mathrm{~L} \mathrm{pot}^{-1}$ treatment $^{-1}$. The planting density was 6 plants $\mathrm{m}^{-2}$. The experimental design was composed of three fertigation treatments, four blocks and four plants (pots) per block giving a total of 48 plants plus adjacent plants. 


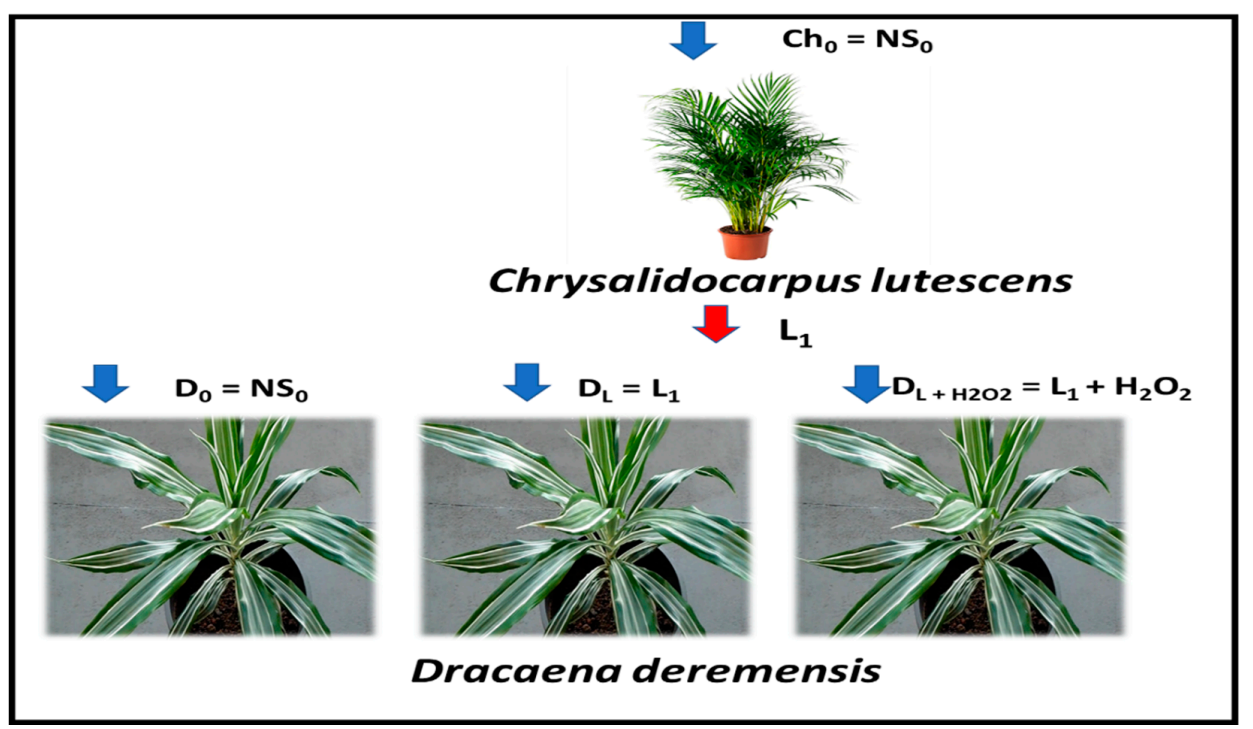

Figure 1. Schematic overview of the experimental design.

\subsection{Monitoring of Irrigation and Leachate Composition}

The samples of nutrient solution applied and the leachates resulting from each fertigation treatment of $\mathrm{D}$. deremensis plants were collected weekly during the whole experimental period ( 8 weeks). The collection of the leachate was performed by placing a plastic collection bucket under each pot. To prevent evaporation of the leachate treatments during the experimental period, the buckets were tightly fitted to the pots. Aliquots of $5 \mathrm{~mL}$ of nutrient solution or leachates were collected and filtered using membrane filters $(0.45 \mu \mathrm{m})$ and frozen for further analysis. The determination of $\mathrm{pH}$ and $\mathrm{EC}$ was assessed with $\mathrm{pH}$ meter and conductivity meter (models Milwaukee pH52 and C66), respectively. The chemical determinations of anions and cations concentration were conducted through high performance liquid chromatography (HPLC) following the protocol reported by Csáky and Martínez-Grau [18].

\subsection{Yield and Water Productivity}

At the end of the harvesting, four plants per fertigation treatment were randomly selected. For each plant, we calculated the volume of applied water, leached and the percentage of leachate over the experimental period. The same plants were used for the determination of fresh weight (FW). Then, we calculated the water productivity in each treatment as the increase in FW between the beginning and the end of the experimental period divided by the volume of total water applied (grams of FW per L of water applied).

\subsection{Ornamental Parameters and Pigments Concentration}

Morphological parameters such as plant height, root length, leaf number, RGB values and pigment concentrations were recorded after harvesting. The plant height was measured with a ruler from the top of the last open leaf of the plant to the substrate line and the longest root length was then measured with a ruler from the crown to the tip of the root. Leaf number was counted directly. The determination of color index in leaves (RGB values) was assessed using the protocol recommended by García-Caparros et al. [19,20] and values were recorderd with an optical scanner (ES-2000; Seiko Epson Corp., Suwa, Japan) and the images were assessed with the program Adobe Photoshop CS6 (Adobe System Software, Dublin, Ireland) by averaging the R, G, and B values (adimensional units) of all the leaf pixels. The same leaves used for the determination of color index were then used for the determination of pigments concentration. Fresh samples of leaves $(0.2 \mathrm{~g})$ were submerged in methanol for $24 \mathrm{~h}$ under dark conditions at room temperature (RT). The supernatant 
was removed, and the pigments concentration was recorded spectrophotometrically using the protocol reported by Wellburn [21].

\subsection{Biomass Parameters}

At the end of the experimental period, four plants were randomly selected per treatment and splitted into three fractions: roots, stems, and leaves. Then, these fractions were washed with distilled water and dried with blotting paper. To determine the dry weight of these fractions, each fraction was oven dried at $60{ }^{\circ} \mathrm{C}$ for $48 \mathrm{~h}$. These dry weights were used to determine several plant parameters as relative leaf weight ratio (LWR; leaf DW per unit plant DW), stem weight ratio (SWR; stem DW per unit plant DW), and root weight ratio (RWR; root DW per unit plant DW) described by Garcia-Caparros et al. [22,23]. The total plant dry weight (TDW) was calculated as the DW sum of the roots, stems, and leaves. The fresh and dry weight of roots, stems and leaves were used to calculate the plant water content (WC) (-) as indicated by Ben Amor et al. [24].

\subsection{Biochemical Determinations}

At the end of the experimental period, four plants were randomly selected per treatment for the determination of total soluble sugar and proline concentration in roots and leaves. Fresh material of roots and leaves $(0.5 \mathrm{~g})$ was crushed with ethanol $(5 \mathrm{~mL}$ at $96 \%)$ and then washed with ethanol ( $5 \mathrm{~mL}$ at $70 \%)$. The alcoholic extract was centrifuged for $10 \mathrm{~min}(3500 \times \mathrm{g})$ and then the supernatant was stored at $4{ }^{\circ} \mathrm{C}$ for further analysis. The alcoholic extract supernatant was used to determine the total soluble sugar and free proline concentrations. The anthrone reagent method was used to determine the total soluble sugar concentrations (expressed in $\mathrm{mg}$ glucose $\mathrm{g}^{-1} \mathrm{FW}$ ). The ninhydrin reagent method was used to determine the free proline concentration (expressed in $\mu \mathrm{g} \mathrm{g}^{-1} \mathrm{FW}$ ) following the recommendations given by Irigoyen et al. [25].

\subsection{Nutrient Balance}

At the end of the experiment, a nutrient balance for each fertigation treatment was recorded using the protocol established by García-Caparrós et al. [26,27]. The amount of nutrient supplied per plant (expressed in $\mathrm{mg}$ ) in each treatment was calculated by multiplying the volume applied in each fertigation treatment by the nutrient concentration. To determine the plant nutrient uptake, the oven-dried samples were ground with a mill and split into two subsamples. The determination of the soluble $\mathrm{N}_{-} \mathrm{NO}_{3}{ }^{-}$was carried out through HPLC in one subsample. The other subsample was mineralized with $\mathrm{H}_{2} \mathrm{SO}_{4}$ $(96 \%)$ and hydrogen peroxide (P-free) at $300{ }^{\circ} \mathrm{C}$ for the determination of total $\mathrm{P}$ [28], organic $\mathrm{N}$ [29], and $\mathrm{K}^{+}$[30] concentration. The total $\mathrm{N}$ concentration in the different organs assessed was calculated as the sum of the organic $\mathrm{N}$ and $\mathrm{N}^{-\mathrm{NO}_{3}}{ }^{-}$concentration. From these determinations and with the previous recording of the dry weight in the different fractions, we computed the plant nutrient uptake as the difference of plant nutrient content at the end and at the beginning of the experiment. An initial harvest at the beginning of the experiment gave an average of $76 \pm 4 \mathrm{mg} \mathrm{N}, 8 \pm 0.5 \mathrm{mg} \mathrm{P}$, and $276 \pm 15.8 \mathrm{mg} \mathrm{K}$ per plant. The percentage of nutrient uptake efficiency was calculated as the ratio between plant nutrient uptake $(\mathrm{mg})$ and plant nutrient supplies $(\mathrm{mg})$ expressed in percentage. The nutrient leached per plant (expressed in $\mathrm{mg}$ ) in each treatment was calculated using the data recorded in the chemical composition of the leachate by their respective leached volume. The percentage of nutrient leachates was calculated as the ratio between nutrient leached per plant and nutrient supplied per plant expressed as a percentage. Nutrients available in the substrate were extracted in ultrapure water $(1: 10 v / v$, substrate-water $)$ using the protocol reported by Sonneveld et al. [31]. The mixture of substrate-water was subjected to shaking for $1 \mathrm{~h}$ and the extract was filtered. An aliquot of $5 \mathrm{~mL}$ of the filtered extract was determined by HPLC as described by Csáky and Martínez-Grau [18]. From these determinations, the amount of nutrient available in the substrate per pot was obtained multiplying by the apparent density of the substrate and by the pot's volume. The amount 
of nutrients retained in the substrate were calculated as the difference between the amount of nutrients at the end and at the beginning of the experiment. Unaccounted nutrients were calculated as the difference between nutrient supplies per plant, nutrient leached and nutrient retained in the substrate. Unaccounted loss was expressed as a percentage dividing the value of unaccounted loss by the total nutrient supplied per plant expressed as a percentage.

\subsection{Statistical Analysis}

The experiment was designed as a randomized block design, where each parameter assessed in each plant was considered as independent replicates. Statgraphics Centurion XVI.II (Statpoint Technologies, Inc. Warrenton, VA, USA) was used to compare between treatments applying one-way analysis of variance (ANOVA) and Fisher's Least Significant Difference (LSD) tests.

\section{Results}

\subsection{Chemical Composition of the Nutrient Solution}

The fertigation with leachates from Chrysalidocarpus lutescens with and without $\mathrm{H}_{2} \mathrm{O}_{2}$ $\left(\mathrm{D}_{\mathrm{L}}\right.$ and $\left.\mathrm{D}_{\mathrm{L}}+\mathrm{H}_{2} \mathrm{O}_{2}\right)$ had higher values of $\mathrm{pH}$ and $\mathrm{EC}$ with respect to the control treatment or standard nutrient solution $\left(\mathrm{D}_{0}\right)$. The fertigation with the leachates with and without $\mathrm{H}_{2} \mathrm{O}_{2}\left(\mathrm{D}_{\mathrm{L}}\right.$ and $\left.\mathrm{D}_{\mathrm{L}+\mathrm{H}_{2} \mathrm{O}_{2}}\right)$ showed higher concentrations of $\mathrm{NO}_{3}{ }^{-}, \mathrm{Cl}^{-}, \mathrm{Ca}^{2+}, \mathrm{Mg}^{2+}, \mathrm{K}^{+}$ and $\mathrm{Na}^{+}$. Regarding $\mathrm{H}_{2} \mathrm{PO}_{4}{ }^{-}$concentration, there were no statistical differences among fertigation treatments. The control treatment or standard nutrient solution showed the highest $\mathrm{H}_{2} \mathrm{PO}_{4}{ }^{-}$and $\mathrm{SO}_{4}{ }^{2-}$ concentration (Table 1).

Table 1. Chemical properties of the fertigation in each treatment: $\mathrm{D}_{0}$-standard nutrient solution or control treatment, $\mathrm{D}_{\mathrm{L}}$-raw leachate treatment and $\mathrm{D}_{\mathrm{L}}+\mathrm{H}_{2} \mathrm{O}_{2}$-raw leachate blended with $\mathrm{H}_{2} \mathrm{O}_{2}$ treatment. The experiment simulates a cascade cropping system with different leachate treatments of Chrysalidocarpus lutescens as primary or "donor" and Dracaena deremensis as a secondary or "acceptor" plant culture. The nutrient concentration was expressed in $\mathrm{mmol} \mathrm{L}^{-1}$ and EC was expressed in $\mathrm{dS} \mathrm{m}^{-1}$. The results are the average values \pm standard deviation of four samples per fertigation treatment during the experimental period.

\begin{tabular}{cccc}
\hline Parameters & $\mathbf{D}_{\mathbf{0}}$ & $\mathbf{D}_{\mathbf{L}}$ & $\mathbf{D}_{\mathbf{L}+\mathbf{H}_{2} \mathbf{O}_{2}}$ \\
\hline $\mathbf{p H}$ & $6.60 \pm 0.10 \mathrm{~b}$ & $7.96 \pm 0.11 \mathrm{a}$ & $7.88 \pm 0.12 \mathrm{a}$ \\
$\mathbf{E C}$ & $1.90 \pm 0.12 \mathrm{~b}$ & $4.55 \pm 0.24 \mathrm{a}$ & $4.61 \pm 0.25 \mathrm{a}$ \\
$\mathbf{C l}^{-}$ & $3.50 \pm 0.11 \mathrm{~b}$ & $20.94 \pm 2.85 \mathrm{a}$ & $20.88 \pm 2.63 \mathrm{a}$ \\
$\mathbf{N O}_{3}{ }^{-}$ & $6.05 \pm 0.51 \mathrm{~b}$ & $15.87 \pm 1.61 \mathrm{a}$ & $14.32 \pm 1.54 \mathrm{a}$ \\
$\mathbf{H}_{\mathbf{2}} \mathbf{P O}_{4}^{-}$ & $0.70 \pm 0.06 \mathrm{a}$ & $0.30 \pm 0.03 \mathrm{~b}$ & $0.26 \pm 0.03 \mathrm{~b}$ \\
$\mathbf{S O}_{4}{ }^{-}$ & $2.01 \pm 0.04 \mathrm{a}$ & $1.69 \pm 0.09 \mathrm{~b}$ & $1.68 \pm 0.11 \mathrm{~b}$ \\
$\mathbf{N a}^{+}$ & $2.60 \pm 0.08 \mathrm{~b}$ & $12.12 \pm 0.88 \mathrm{a}$ & $12.28 \pm 0.98 \mathrm{a}$ \\
$\mathbf{K}^{+}$ & $3.08 \pm 0.06 \mathrm{~b}$ & $8.14 \pm 0.50 \mathrm{a}$ & $8.18 \pm 0.45 \mathrm{a}$ \\
$\mathbf{C a}^{2+}$ & $2.03 \pm 0.05 \mathrm{~b}$ & $9.55 \pm 0.55 \mathrm{a}$ & $9.53 \pm 0.54 \mathrm{a}$ \\
$\mathbf{M g}^{2+}$ & $1.41 \pm 0.04 \mathrm{~b}$ & $4.44 \pm 0.38 \mathrm{a}$ & $4.40 \pm 0.32 \mathrm{a}$ \\
\hline
\end{tabular}

In each row, different letters indicate significant differences $(p<0.05)$.

It is worthwhile to mention that the chemical composition of the standard nutrient solution or control treatment remained constant over the experiment. As far as anions concentrations was concerned, $\mathrm{Cl}^{-}$concentration in the leachates from $\mathrm{C}$. lutescens with and without $\mathrm{H}_{2} \mathrm{O}_{2}$ showed higher values than the control treatment and did not show a clear trend during the experimental period. Nitrate concentration in the leachates showed the highest values in the first weeks of the experimental period and then tended to decrease over the experiment, being always higher than in the control treatment. In the case of phosphate concentration, the fertigation with leachates with and without $\mathrm{H}_{2} \mathrm{O}_{2}$ showed similar values over the experiment (around to $0.4 \mathrm{mmol} \mathrm{L}^{-1}$ ) being lower than the control treatment (around $0.7 \mathrm{mmol} \mathrm{L}^{-1}$ ). Regarding sulphate concentration, the different treatments 
assessed ranged from 1.7 to $2.5 \mathrm{mmol} \mathrm{L}^{-1}$ (Figure 2A). Considering cations concentration, it is necessary to point out that the control treatment or standard nutrient solution showed the lowest values during the experimental period. Sodium concentration in the leachates from $C$. lutescens with and without $\mathrm{H}_{2} \mathrm{O}_{2}$ tended to increase over the experimental period, whereas potassium, calcium and magnesium showed a slight trend to decrease throughout the experiment (Figure 2B).
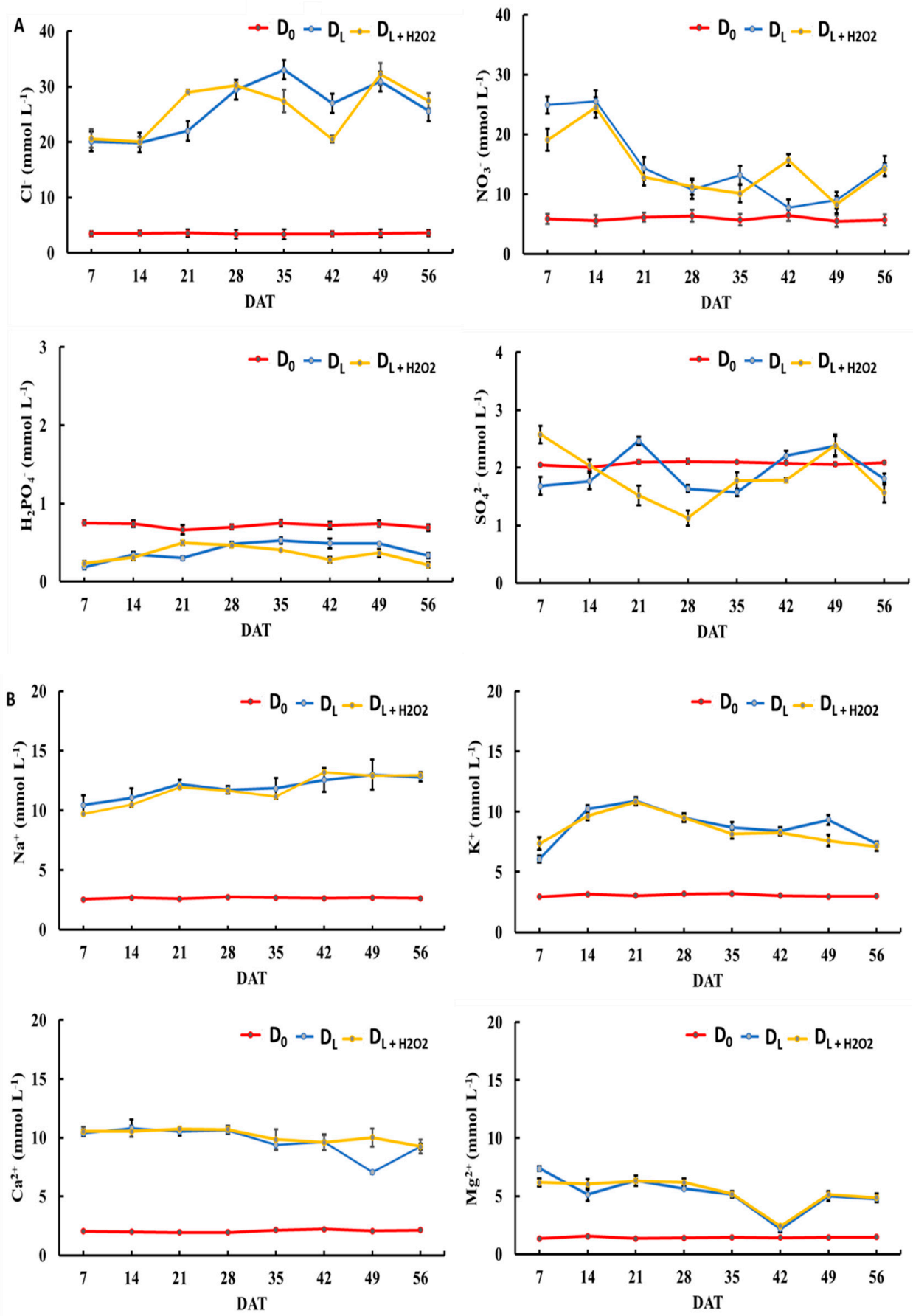

Figure 2. Anions and cations concentration $(\mathbf{A}, \mathbf{B})$ in the different fertigation treatments throughout the experimental period. $\mathrm{D}_{0}$-standard nutrient solution or control treatment, $\mathrm{D}_{\mathrm{L}}$-raw leachate treatment and $\mathrm{D}_{\mathrm{L}}+\mathrm{H}_{2} \mathrm{O}_{2}$-raw leachate blended with $\mathrm{H}_{2} \mathrm{O}_{2}$ treatment. The experiment simulates a cascade cropping system with different leachate treatments of Chrysalidocarpus lutescens as primary or "donor" and Dracaena deremensis as a secondary or "acceptor" plant culture. The results are the average values \pm standard deviation of four samples per fertigation treatment during the experimental period. DAT = days after transplanting. 


\subsection{Yield and Water Productivity in Plants}

The plants subjected to different fertigation treatments received the same volume during the experimental period $\left(10.2 \mathrm{~L} \mathrm{~m}^{-2}\right)$. The volume of leachate generated and consequently the leachate fraction and the water uptake were similar in all treatments. Dracaena deremensis fertigated with leachates with $\mathrm{H}_{2} \mathrm{O}_{2}$ showed the highest values in total yield (expressed in $g$ of plant fresh weight $(\mathrm{FW}) \mathrm{m}^{-2}$ ) and water productivity (expressed in $\mathrm{g}$ of fresh weight per $\mathrm{L}$ of water applied) (Table 2).

Table 2. Volume of irrigation water applied, water uptake, leachate volume collected, leachate fraction, yield and water productivity of $D$. deremensis plants in each fertigation treatment: $\mathrm{D}_{0}$-standard nutrient solution or control treatment, $\mathrm{D}_{\mathrm{L}}$-raw leachate treatment and $\mathrm{D}_{\mathrm{L}}+\mathrm{H}_{2} \mathrm{O}_{2}$-raw leachate blended with $\mathrm{H}_{2} \mathrm{O}_{2}$ treatment. The experiment simulates a cascade cropping system with different leachate treatments of Chrysalidocarpus lutescens as primary or "donor" and Dracaena deremensis as a secondary or "acceptor" plant culture. The results are expressed as means \pm standard deviation $(\mathrm{n}=4)$. In each row, same letters indicate non-significant differences $(p<0.05)$.

\begin{tabular}{cccc}
\hline Parameters & $\mathrm{D}_{\mathbf{0}}$ & $\mathrm{D}_{\mathrm{L}}$ & $\mathrm{D}_{\mathrm{L}+\mathrm{H}_{2} \mathrm{O}_{2}}$ \\
\hline Irrigation water applied $\left(\mathrm{L} \mathrm{m}^{-2}\right)$ & $10.2 \mathrm{a}$ & $10.2 \mathrm{a}$ & $10.2 \mathrm{a}$ \\
Water uptake & $7.0 \pm 0.5 \mathrm{a}$ & $7.1 \pm 0.5 \mathrm{a}$ & $7.0 \pm 0.6 \mathrm{a}$ \\
Leachate $\left(\mathrm{L} \mathrm{m}^{-2}\right)$ & $3.1 \pm 0.3 \mathrm{a}$ & $2.9 \pm 0.3 \mathrm{a}$ & $3.1 \pm 0.3 \mathrm{a}$ \\
Leachate fraction $(\%)$ & $30 \mathrm{a}$ & $30 \mathrm{a}$ & $30 \mathrm{a}$ \\
Yield $\left(\mathrm{g} \mathrm{FW} \mathrm{m}{ }^{-2}\right)$ & $150.1 \pm 12.7 \mathrm{~b}$ & $122.5 \pm 10.8 \mathrm{c}$ & $241.3 \pm 19.8 \mathrm{a}$ \\
Water productivity (g of FW per & $14.2 \pm 1.0 \mathrm{~b}$ & $12.1 \pm 0.8 \mathrm{c}$ & $23.9 \pm 2.5 \mathrm{a}$ \\
L of water applied) & & & \\
\hline
\end{tabular}

\subsection{Ornamental Parameters and Pigments Concentrations}

Root length and leaf number had the highest value in plants fertigated with the standard nutrient solution. The fertigation with leachates from $C$. lutescens did not vary the plant height with respect to the control treatment (fertigation with standard nutrient solution), but the addition of $\mathrm{H}_{2} \mathrm{O}_{2}$ to the leachate improved the plant height compared to the control treatment. Regarding color index, D. deremensis plants fertigated with leachates with or without $\mathrm{H}_{2} \mathrm{O}_{2}$ showed a decline in the values of $\mathrm{R}, \mathrm{G}$ and $\mathrm{B}$ compared to the control treatment. Chlorophyll $\mathrm{a}, \mathrm{b}$ and $\mathrm{chl}(\mathrm{a}+\mathrm{b})$ showed the highest value in plants fertigated with the standard nutrient solution (Table 3).

\subsection{Biomass Parameters}

Dracaena deremensis plants fertigated with leachates from C. lutescens without $\mathrm{H}_{2} \mathrm{O}_{2}$ showed the lowest value of root and shoot dry weight. Leaf and total dry weight were higher in plants fertigated with leachate with $\mathrm{H}_{2} \mathrm{O}_{2}$. The root, shoot and leaf weight ratio remained without changes under the different fertigation treatments. Plant water content showed the highest value in plants fertigated with leachate with $\mathrm{H}_{2} \mathrm{O}_{2}$ (Table 4).

\subsection{Biochemical Determinations}

Plants fertigated with leachates from $C$. lutescens with and without $\mathrm{H}_{2} \mathrm{O}_{2}$ increased proline concentration in roots and leaves compared to plants fertigated with the standard nutrient solution. With respect to total soluble sugar concentration, plants fertigated with leachates had the highest value of total soluble sugar concentration in root while plants fertigated with the standard nutrient solution had the highest value of leaf total soluble sugar concentration (Table 5). 


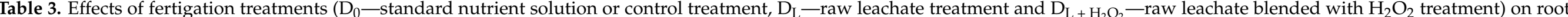

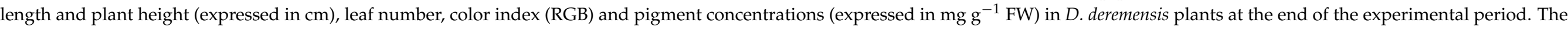

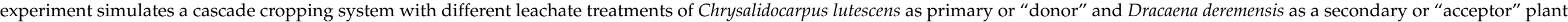
culture. The results are expressed as means \pm standard deviation $(n=4)$. In each column, same letters indicate non-significant differences $(p<0.05)$.

\begin{tabular}{|c|c|c|c|c|c|c|c|c|c|}
\hline \multirow{2}{*}{ Treatments } & \multirow{2}{*}{ Root Length } & \multirow[t]{2}{*}{ Plant Height } & \multirow[t]{2}{*}{ Leaf Number } & \multicolumn{3}{|c|}{ Color Index } & \multicolumn{3}{|c|}{ Pigment Concentrations } \\
\hline & & & & Red & Green & Blue & Chl a & Chl b & Chl $(a+b)$ \\
\hline $\mathrm{D}_{0}$ & $41.25 \pm 2.75 \mathrm{a}$ & $35.53 \pm 1.74 b$ & $23.00 \pm 2.04 \mathrm{a}$ & $111.25 \pm 7.66 \mathrm{a}$ & $109.07 \pm 6.92 \mathrm{a}$ & $86.05 \pm 6.58 \mathrm{a}$ & $0.06 \pm 0.01 \mathrm{a}$ & $0.70 \pm 0.06 \mathrm{a}$ & $0.75 \pm 0.06 \mathrm{a}$ \\
\hline $\mathrm{D}_{\mathrm{L}}$ & $33.75 \pm 2.22 b$ & $34.13 \pm 1.65 b$ & $17.50 \pm 1.29 b$ & $88.50 \pm 5.72 b$ & $85.18 \pm 5.05 b$ & $56.55 \pm 3.43 b$ & $0.02 \pm 0.01 \mathrm{~b}$ & $0.42 \pm 0.04 c$ & $0.45 \pm 0.04 c$ \\
\hline $\mathrm{D}_{\mathrm{L}+\mathrm{H}_{2} \mathrm{O}_{2}}$ & $34.13 \pm 2.46 b$ & $40.25 \pm 1.89 \mathrm{a}$ & $19.00 \pm 1.63 b$ & $84.10 \pm 4.69 \mathrm{~b}$ & $87.25 \pm 5.25 b$ & $53.95 \pm 3.68 b$ & $0.03 \pm 0.01 b$ & $0.55 \pm 0.05 b$ & $0.60 \pm 0.06 b$ \\
\hline
\end{tabular}

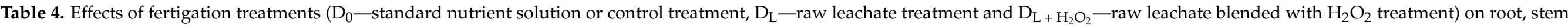

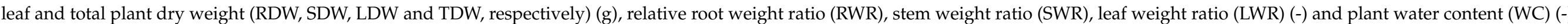

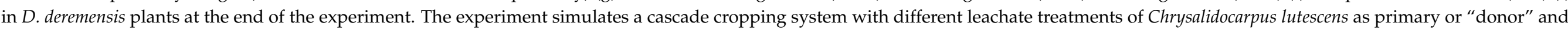

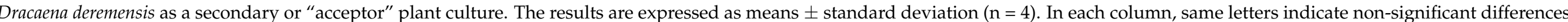
$(p<0.05)$.

\begin{tabular}{|c|c|c|c|c|c|c|c|c|}
\hline Treatments & RDW & SDW & LDW & TDW & RWR & SWR & LWR & WC \\
\hline $\mathrm{D}_{0}$ & $2.56 \pm 0.24 \mathrm{a}$ & $1.27 \pm 0.07 \mathrm{a}$ & $6.97 \pm 0.61 b$ & $10.60 \pm 0.64 b$ & $0.23 \pm 0.02 \mathrm{a}$ & $0.12 \pm 0.01 \mathrm{a}$ & $0.65 \pm 0.05 a$ & $1.27 \pm 0.10 \mathrm{~b}$ \\
\hline$D_{L}$ & $1.88 \pm 0.16 b$ & $1.10 \pm 0.07 \mathrm{~b}$ & $7.08 \pm 0.60 \mathrm{~b}$ & $9.17 \pm 0.56 c$ & $0.21 \pm 0.02 \mathrm{a}$ & $0.12 \pm 0.01 \mathrm{a}$ & $0.67 \pm 0.05 a$ & $1.22 \pm 0.09 \mathrm{~b}$ \\
\hline $\mathrm{D}_{\mathrm{L}+\mathrm{H}_{2} \mathrm{O}_{2}}$ & $2.45 \pm 0.21 \mathrm{a}$ & $1.31 \pm 0.08 \mathrm{a}$ & $8.78 \pm 0.72 \mathrm{a}$ & $12.30 \pm 0.68 \mathrm{a}$ & $0.21 \pm 0.02 \mathrm{a}$ & $0.11 \pm 0.01 \mathrm{a}$ & $0.68 \pm 0.06 \mathrm{a}$ & $2.33 \pm 0.19 \mathrm{a}$ \\
\hline
\end{tabular}


Table 5. Effects of fertigation treatments $\left(\mathrm{D}_{0}\right.$-standard nutrient solution or control treatment, $\mathrm{D}_{\mathrm{L}}-$ raw leachate treatment and $\mathrm{D}_{\mathrm{L}}+\mathrm{H}_{2} \mathrm{O}_{2}$-raw leachate blended with $\mathrm{H}_{2} \mathrm{O}_{2}$ treatment) on root and leaf proline and total soluble sugar concentration in $D$. deremensis plants at the end of the experiment. The experiment simulates a cascade cropping system with different leachate treatments of Chrysalidocarpus lutescens as primary or "donor" and Dracaena deremensis as a secondary or "acceptor" plant culture. The results are expressed as means \pm standard deviation $(n=4)$. In each column, same letters indicate non-significant differences $(p<0.05)$.

\begin{tabular}{cccc}
\hline & Treatments & Roots & Leaves \\
\hline \multirow{2}{*}{ Proline $\left(\mu \mathrm{g} \mathrm{g}^{-1} \mathrm{FW}\right)$} & $\mathrm{D}_{0}$ & $25.56 \pm 2.21 \mathrm{~b}$ & $83.45 \pm 6.32 \mathrm{~b}$ \\
& $\mathrm{D}_{\mathrm{L}}$ & $34.89 \pm 2.52 \mathrm{a}$ & $103.90 \pm 8.52 \mathrm{a}$ \\
& $\mathrm{D}_{\mathrm{L}+\mathrm{H}_{2} \mathrm{O}_{2}}$ & $34.12 \pm 2.45 \mathrm{a}$ & $105.18 \pm 8.45 \mathrm{a}$ \\
\hline \multirow{2}{*}{ Total soluble sugars } & $\mathrm{D}_{0}$ & $5.49 \pm 0.29 \mathrm{c}$ & $7.37 \pm 0.54 \mathrm{a}$ \\
$\left(\mathrm{mg} \mathrm{g}^{-1} \mathrm{FW}\right)$ & $\mathrm{D}_{\mathrm{L}}$ & $7.07 \pm 0.36 \mathrm{a}$ & $3.57 \pm 0.23 \mathrm{c}$ \\
& $\mathrm{D}_{\mathrm{L}+\mathrm{H}_{2} \mathrm{O}_{2}}$ & $6.44 \pm 0.32 \mathrm{~b}$ & $5.39 \pm 0.30 \mathrm{~b}$ \\
\hline
\end{tabular}

\subsection{Nutrient Balance}

The amount of $\mathrm{N}$ and $\mathrm{K}$ supplied per plant declined in plants fertigated with leachates from $C$. lutescens with and without $\mathrm{H}_{2} \mathrm{O}_{2}$, whereas in the case of $\mathrm{P}$, there were no significant differences between fertigation treatments. Plant nutrient uptake showed the highest value in plants fertigated with leachates with $\mathrm{H}_{2} \mathrm{O}_{2}$. Nitrogen and $\mathrm{P}$ uptake efficiency showed the highest value in plants fertigated with leachates with $\mathrm{H}_{2} \mathrm{O}_{2}$, whereas in the case of $\mathrm{K}$, the fertigation with leachates without $\mathrm{H}_{2} \mathrm{O}_{2}$ showed the lowest value. Nitrogen and $\mathrm{K}$ leached per plant increased in plants fertigated with leachates with and without $\mathrm{H}_{2} \mathrm{O}_{2}$ compared to plants fertigated with the standard nutrient solution, while in phosphorus, plants fertigated with the nutrient solution showed the highest value. The percentages of nutrient runoff in our experiment were for $\mathrm{N}(32-41 \%), \mathrm{P}(31-58 \%)$ and $\mathrm{K}(36-37 \%)$. Regarding nutrients in substrate, $\mathrm{N}$ and $\mathrm{P}$ had the highest value in plants fertigated with leachates with $\mathrm{H}_{2} \mathrm{O}_{2}$, whereas in $\mathrm{K}$, the highest value was in plants fertigated with leachates without $\mathrm{H}_{2} \mathrm{O}_{2}$. Unaccounted nitrogen remained without changes under different fertigation treatments, while in the case of $\mathrm{P}$ and $\mathrm{K}$, plants fertigated with leachates without $\mathrm{H}_{2} \mathrm{O}_{2}$ showed the highest value (Table 6). 


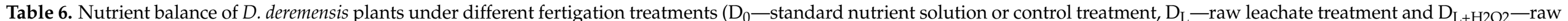

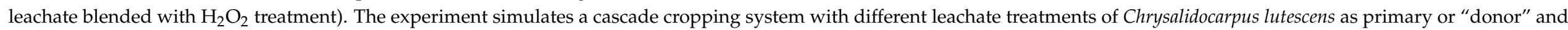

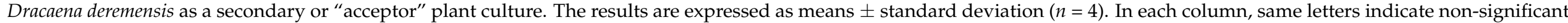
differences $(p<0.05)$.

\begin{tabular}{|c|c|c|c|c|c|c|c|c|c|}
\hline & Treatments & $\begin{array}{c}\text { Nutrient } \\
\text { Supplied per } \\
\text { Plant (mg) }\end{array}$ & $\begin{array}{l}\text { Plant Nutrient } \\
\text { Uptake (mg) }\end{array}$ & $\begin{array}{c}\text { Nutrient } \\
\text { Uptake } \\
\text { Efficiency (\%) }\end{array}$ & $\begin{array}{l}\text { Nutrient } \\
\text { Leached per } \\
\text { Plant (mg) }\end{array}$ & $\begin{array}{c}\text { Nutrient } \\
\text { Leachates (\%) }\end{array}$ & $\begin{array}{l}\text { Substrate } \\
\text { (mg) }\end{array}$ & $\begin{array}{l}\text { Unaccounted } \\
\text { Nutrient (mg) }\end{array}$ & $\begin{array}{l}\text { Unaccounted } \\
\text { Loss }(\%)\end{array}$ \\
\hline \multirow[t]{3}{*}{$\mathbf{N}$} & $\mathrm{D}_{0}$ & $145.1 \pm 14.3 \mathrm{a}$ & $20.1 \pm 1.7 c$ & $13.9 \pm 1.1 c$ & $45.9 \pm 4.7 \mathrm{~b}$ & $31.9 \pm 2.5 b$ & $4.7 \pm 0.3 c$ & $76.5 \pm 8.1 \mathrm{a}$ & $50.9 \pm 5.0 \mathrm{a}$ \\
\hline & $\mathrm{D}_{\mathrm{L}}$ & $269.4 \pm 26.2 b$ & $60.5 \pm 5.4 b$ & $22.5 \pm 2.0 \mathrm{~b}$ & $110.7 \pm 9.8 \mathrm{a}$ & $41.1 \pm 3.8 \mathrm{a}$ & $7.5 \pm 0.6 b$ & $90.4 \pm 8.7 \mathrm{a}$ & $33.6 \pm 3.3 b$ \\
\hline & $\mathrm{D}_{\mathrm{L}+\mathrm{H}_{2} \mathrm{O}_{2}}$ & $287.2 \pm 28.0 \mathrm{~b}$ & $91.3 \pm 8.6 \mathrm{a}$ & $31.8 \pm 3.0 \mathrm{a}$ & $105.1 \pm 10.7 \mathrm{a}$ & $36.6 \pm 3.5 \mathrm{a}$ & $12.3 \pm 1.1 \mathrm{a}$ & $78.6 \pm 7.4 \mathrm{a}$ & $27.3 \pm 2.9 \mathrm{~b}$ \\
\hline \multirow[t]{3}{*}{$\mathbf{P}$} & $\mathrm{D}_{0}$ & $37.6 \pm 2.8 \mathrm{a}$ & $3.7 \pm 0.3 b$ & $9.8 \pm 0.9 b$ & $21.8 \pm 2.1 \mathrm{a}$ & $57.9 \pm 5.3 \mathrm{a}$ & $4.2 \pm 0.3 b$ & $7.6 \pm 0.8 b$ & $21.1 \pm 2.0 \mathrm{~b}$ \\
\hline & $\mathrm{D}_{\mathrm{L}}$ & $33.5 \pm 2.7 \mathrm{a}$ & $1.1 \pm 0.1 \mathrm{c}$ & $3.2 \pm 0.3 c$ & $11.8 \pm 1.0 \mathrm{~b}$ & $35.5 \pm 3.1 \mathrm{~b}$ & $2.5 \pm 0.2 c$ & $18.1 \pm 1.6 \mathrm{a}$ & $53.8 \pm 5.2 \mathrm{a}$ \\
\hline & $\mathrm{D}_{\mathrm{L}}+\mathrm{H}_{2} \mathrm{O}_{2}$ & $35.7 \pm 3.1 \mathrm{a}$ & $9.1 \pm 0.8 \mathrm{a}$ & $24.5 \pm 2.4 \mathrm{a}$ & $11.2 \pm 0.9 \mathrm{~b}$ & $31.4 \pm 2.9 \mathrm{~b}$ & $8.7 \pm 0.8 \mathrm{a}$ & $6.7 \pm 0.5 \mathrm{~b}$ & $18.7 \pm 2.0 \mathrm{~b}$ \\
\hline \multirow[t]{3}{*}{ K } & $\mathrm{D}_{0}$ & $200.6 \pm 20.3 a$ & $114.2 \pm 11.1 \mathrm{~b}$ & $56.9 \pm 5.3 \mathrm{a}$ & $72.4 \pm 6.8 \mathrm{~b}$ & $36.1 \pm 3.3 \mathrm{a}$ & $0.2 \pm 0.01 \mathrm{c}$ & $13.8 \pm 1.5 c$ & $6.8 \pm 0.6 c$ \\
\hline & $\mathrm{D}_{\mathrm{L}}$ & $451.5 \pm 40.7 \mathrm{~b}$ & $120.0 \pm 10.5 b$ & $26.6 \pm 2.4 \mathrm{~b}$ & $167.2 \pm 15.8 \mathrm{a}$ & $37.1 \pm 3.9 \mathrm{a}$ & $0.6 \pm 0.02 \mathrm{a}$ & $163.6 \pm 13.9 \mathrm{a}$ & $36.2 \pm 3.2 \mathrm{a}$ \\
\hline & $\mathrm{D}_{\mathrm{L}}+\mathrm{H}_{2} \mathrm{O}_{2}$ & $481.3 \pm 39.8 \mathrm{~b}$ & $238.4 \pm 21.7 \mathrm{a}$ & $49.5 \pm 4.4 \mathrm{a}$ & $173.3 \pm 14.4 \mathrm{a}$ & $35.9 \pm 3.4 \mathrm{a}$ & $0.4 \pm 0.03 \mathrm{~b}$ & $69.8 \pm 6.4 \mathrm{~b}$ & $14.4 \pm 1.2 \mathrm{~b}$ \\
\hline
\end{tabular}




\section{Discussion}

Regarding fertigation treatments of $D$. deremensis, there was a rise of $\mathrm{pH}$ after irrigation with leachates from Chrysalidocarpus lutescens with and without $\mathrm{H}_{2} \mathrm{O}_{2}$ compared to the fertigation with a standard nutrient solution, and this fact can be related to the release of $\mathrm{OH}^{-}$as it has been reported in similar systems [32]. The EC increase in the leachate can be ascribed to the increase in $\mathrm{Na}^{+}$and $\mathrm{Cl}^{-}$concentration as has been reported in other crops irrigated with leachates $[27,33]$. The reuse of leachates and the high presence of $\mathrm{Cl}^{-}$, $\mathrm{Ca}^{2+}, \mathrm{Mg}^{2+}$ and $\mathrm{Na}^{+}$in the tap water could be due the reason for their accumulation in the fertigation with leachates over time as previously reported by Massa et al. [34]. The decrease in $\mathrm{H}_{2} \mathrm{PO}_{4}{ }^{-}$and $\mathrm{SO}_{4}{ }^{2-}$ in leachates over time may be related to specific nutrient requirements of the previous crop for the maintenance of some physiological processes [35].

Considering the same volume of fertigation in each treatment and also that the water uptake and the volume of leachate was similar among fertigation treatments, it is necessary to highlight that the percentage of leachate fraction obtained in our experiment $(30 \%)$ was in line with the range from $25 \%$ to $30 \%$ previously reported by García-Caparrós et al. [27] in a cascade cropping system with melon and rosemary plants. Although the fertigation with leachates resulted in a significant reduction in yield and water productivity with respect to the control treatment, the addition of $\mathrm{H}_{2} \mathrm{O}_{2}$ resulted in an improvement in yield and crop water productivity in D. deremensis plants. Similar results were reported in several crops such as zucchini and tomato by Bhattarai et al. $[10,36]$ in enhanced oxygation conditions, which are also achieved through the addition of hydrogen peroxide to the fertigation treatments.

The addition of hydrogen peroxide in the leachate from C. lutescens used for fertigation enhanced the plant height in $D$. deremensis plants. The increase in plant height can be due to a higher amount of oxygen available for root respiration [37] as a consequence of the addition of hydrogen peroxide and also may be due to the enhancement of auxins synthesis via $\mathrm{H}_{2} \mathrm{O}_{2}$ signaling as reported by Joo et al. [38]. The decrease in root length and leaf number in $D$. deremensis plants fertigated with leachates with and without $\mathrm{H}_{2} \mathrm{O}_{2}$ with respect to the control treatment can be ascribed to the fact that leachates with higher EC resulted in a reduction in root length and leaf number mainly due to the high presence of toxic ions $\left(\mathrm{Na}^{+}\right.$and $\left.\mathrm{Cl}^{-}\right)$[2].

The decline in color index $(\mathrm{R}, \mathrm{G}$ and $\mathrm{B})$ in $D$. deremensis plants fertigated with leachates from $C$. lutescens with or without $\mathrm{H}_{2} \mathrm{O}_{2}$ agree with the reports obtained by García-Caparrós et al. [39], where the irrigation with leachates resulted in a decline in color parameters in Maytenus senegalensis plants. Although there was a decline in color parameters, the leaf color ranges characteristic of this species allowed the obtention of saleable plants considering the sales threshold established by local nurseries, since there were no symptoms of chlorosis or necrosis associated with the increase in salinity in the leachate.

The fertigation of $D$. deremensis with leachates from C. lutescens resulted in a decline in $\mathrm{Chl} b$ and $(\mathrm{a}+\mathrm{b})$ concentration compared to the fertigation with the control treatment. It has been argued that under high EC or saline conditions, there is a reduction in chlorophyll synthesis and the activation of its degradation by the enzyme chlorophyllase [40]. Nevertheless, the addition of $\mathrm{H}_{2} \mathrm{O}_{2}$ to the leachate for the fertigation resulted in an increase in pigment concentration compared with plants fertigated only with leachates. This enhancement of pigment concentration can be due to the addition of hydrogen peroxide and the consequent improvement in plant root respiration and photosynthetic rate as reported by Li et al. [41] and Zhao et al. [42] under oxygation conditions.

Dracaena deremensis plants fertigated with leachates resulted in a significant decline in the different biomass parameters assessed compared to the fertigation with the standard nutrient solution, but the addition of $\mathrm{H}_{2} \mathrm{O}_{2}$ to the leachate enhanced significantly these biomass parameters, being higher than the control treatment in the case of leaf and total dry weight. This biomass enhancement obtained in our experiment agrees with the results obtained by Hameed et al. [43] in wheat and Gil et al. [44] in avocado. These results are indicative of the positive effect of the addition of hydrogen peroxide in the fertigation 
treatment for the growth of this species. No variations in root, shoot and leaf weight ratio reported in our experiment in $D$. deremensis plants under different fertigation treatments can be ascribed to the duration of the experiment. The increase in plant water content in plants fertigated with leachates with $\mathrm{H}_{2} \mathrm{O}_{2}$ can be ascribed to the ameliorative effect of the exogenous supply of $\mathrm{H}_{2} \mathrm{O}_{2}$ in crops already mentioned.

The fertigation with leachates from C. lutescens with and without $\mathrm{H}_{2} \mathrm{O}_{2}$ resulted in an increase in root and leaf proline concentration in $D$. deremensis plants with respect to fertigated plants with the standard nutrient solution. The proline increase as a consequence of the fertigation with leachates can be associated with the protective role of this osmolyte against stressful conditions such as the salt increase level in the nutrient solution as reported by Szabados and Savoure [45]. In our experiment, the fertigation with leachates with and without $\mathrm{H}_{2} \mathrm{O}_{2}$ increased root and decreased leaf total soluble sugars with respect to the control treatment. This evidence may suggest a translocation of soluble sugars from leaves to roots as has been already reported under increasing saline conditions [46].

From a nutritional point of view, the decrease in $\mathrm{N}$ and $\mathrm{K}$ supplies in the fertigation with leachates can be ascribed to the nutrient uptake of the previous crop (C. lutescens) as has been reported in other cascade cropping systems [5]. The highest value of nutrient uptake and efficiency in $D$. deremensis plants fertigated with leachates with $\mathrm{H}_{2} \mathrm{O}_{2}$ led to increased plant height and also the total plant dry weight previously explained. Nevertheless, the lower values in nutrient uptake and efficiency in plants fertigated with leachates without $\mathrm{H}_{2} \mathrm{O}_{2}$ did not result in any visual symptoms of nutrient deficiency. Analogously, the fertigation with leachates in a cascade cropping system with rosemary plants [27] resulted in lower nutrient uptake and efficiencies. The ranges of N (14-32), P (10-25) and K (27-57\%) uptake efficiencies reported in this work in all fertigation treatments were similar with the data reported by García-Caparrós et al. [27]. The amount of $\mathrm{N}$ and $\mathrm{K}$ leached per plant expressed in $\mathrm{mg}$ or as percentage increased in plants fertigated with leachates. In our experiment, the amount of nutrient leached per plant ranged from 46 to $110 \mathrm{mg}$ in $\mathrm{N}$, from 11 to $21 \mathrm{mg}$ in $\mathrm{P}$ and from 72 to $173 \mathrm{mg}$ in K. Different results were reported by Ristvey et al. [47], since they recorded values of leachates per plant for N (4-152 mg) and P $(2-16 \mathrm{mg})$ in an experiment with different fertilizer rates. The fertigation with leachates with $\mathrm{H}_{2} \mathrm{O}_{2}$ led to a higher accumulation of $\mathrm{N}$ and $\mathrm{P}$ in the substrate and this fact may be ascribed to the addition of $\mathrm{H}_{2} \mathrm{O}_{2}$ in the leachate and the possible consequent increase in $\mathrm{NO}_{3}{ }^{-}-\mathrm{N}$ and $\mathrm{H}_{2} \mathrm{PO}_{4}{ }^{-} \mathrm{P}$ retention capacity in peat moss [48]. To complete the nutrient balance, unaccounted $\mathrm{N}$ remained without changes under different fertigation treatments, whereas in the case of $\mathrm{P}$ and $\mathrm{K}$ showed the highest values in plants fertigated with leachates without $\mathrm{H}_{2} \mathrm{O}_{2}$. The values expressed in percentage form for nutrient loss showed different trends in plants grown under different fertigation treatments.

\section{Conclusions}

The results obtained in this work reported the positive effect of the addition of $\mathrm{H}_{2} \mathrm{O}_{2}$ in the leachate from $C$. lutescens on plant height, leaf and total dry weight in D. deremensis plants. The fertigation with leachates with or without $\mathrm{H}_{2} \mathrm{O}_{2}$ led to a decline in root length, leaf number, RGB values and pigments concentration. Root and leaf proline concentration increased under the fertigation with leachates with or without $\mathrm{H}_{2} \mathrm{O}_{2}$, whereas in the case of total soluble sugar concentration, there were different trends in roots and leaves, resulting in an accumulation in the root fraction in plants fertigated with leachates. Plant nutrient uptake and efficiency increased significantly in plants fertigated with leachates with $\mathrm{H}_{2} \mathrm{O}_{2}$. Nitrogen and potassium leached per plant increased in plants fertigated with leachates from C. lutescens with or without $\mathrm{H}_{2} \mathrm{O}_{2}$ and unaccounted nutrients showed different trends for each nutrient in the fertigation treatments assessed. These results suggest the importance of understanding how the addition of $\mathrm{H}_{2} \mathrm{O}_{2}$ may affect the metabolism and plant physiology, especially under the reuse of leachates from another ornamental species. 
Author Contributions: P.G.-C. investigation, data curation, writing-original draft preparation, C.V.E. investigation, data curation, M.T.L. conceptualization, supervision, project administration. All authors have read and agreed to the published version of the manuscript.

Funding: This research received no external funding.

Acknowledgments: The authors thank the funding of this work by the group AGR-242 from University of Almería (Sustainability of Horticultural and Ornamental Protected Systems).

Conflicts of Interest: The authors declare no conflict of interest.

\section{References}

1. Boutigny, A.L.; Dohin, N.; Pornin, D.; Rolland, M. Overview and detectability of the genetic modifications in ornamental plants. Hortic. Res. 2020, 7, 1-12. [CrossRef] [PubMed]

2. García-Caparrós, P.; Lao, M.T. The effects of salt stress on ornamental plants and integrative cultivation practices. Sci. Hortic. 2018, 240, 430-439. [CrossRef]

3. Zulfiqar, F.; Allaire, S.E.; Akram, N.A.; Méndez, A.; Younis, A.; Peerzada, A.M.; Shaukat, N.; Wright, S.R. Challenges in organic component selection and biochar as an opportunity in potting substrates: A review. J. Plant Nutr. 2019, 42, 1386-1401. [CrossRef]

4. Warsaw, A.L.; Fernandez, R.T.; Cregg, B.M.; Andresen, J.A. Container-grown ornamental plant growth and water runoff nutrient content and volume under four irrigation treatments. HortScience 2009, 44, 1573-1580. [CrossRef]

5. García-Caparrós, P.; Llanderal, A.; El-Tarawy, A.; Correia, P.J.; Pestana, M.; Lao, M.T. Irrigation with drainage solutions improves the growth and nutrients uptake in Juncus acutus. Ecol. Engin. 2016, 95, 237-244. [CrossRef]

6. Bethune, M.G.; Gyles, O.A.; Wang, Q.J. Options for management of saline ground water in an irrigated farming system. Aus. J. Exp. Agric. 2004, 44, 181-188. [CrossRef]

7. Chen, X.; Dhungel, J.; Bhattarai, S.; Torabi, M.; Midmore, D.J. Impact of oxygation on soil respiration and crop physiological characteristics in pineapple. J. Drain. Irrig. Mach. Engin. 2010, 28, 543-547.

8. Massee, I. The sterilization of seed. Bull. Misc. Inf. 1913, 183-187. [CrossRef]

9. Ben-Noah, I.; Friedman, S.P. Oxygation of clayey soils by adding hydrogen peroxide to the irrigation solution: Lysimetric experiments. Rhizosphere 2016, 2, 51-61. [CrossRef]

10. Bhattarai, S.P.; Su, N.; Midmore, D.J. Oxygation unlocks yield potentials of crops in oxygen-limited soil environments. Adv. Agron. 2005, 88, 313-377.

11. Guzel, S.; Terzi, R. Exogenous hydrogen peroxide increases dry matter production, mineral content and level of osmotic solutes in young maize leaves and alleviates deleterious effects of copper stress. Bot. Stud. 2013, 54, 26. [CrossRef] [PubMed]

12. Carvalho, F.E.L.; Lobo, A.K.M.; Bonifacio, A.; Martins, M.O.; Lima Neto, M.C.; Silveira, J.A.G. Aclimatação ao estresse salino em plantas de arroz induzida pelo pré-tratamento com $\mathrm{H}_{2} \mathrm{O}_{2}$. Rev. Bras. Eng. Agric. Ambient. 2011, 15, 416-423. [CrossRef]

13. Silva, A.A.R.; Lima, G.S.; Azevedo, C.A.V.; Veloso, L.L.S.A.; Gheyi, H.R.; Soares, L.A.A. Salt stress and exogenous application of hydrogen peroxide on photosynthetic parameters of soursop. Rev. Bras. Eng. Agric. Ambient. 2019, 23, 257-263. [CrossRef]

14. Zulfiqar, F.; Younis, A.; Asif, M.; Abideen, Z.; Allaire, S.E.; Shao, Q.S. Evaluation of container substrates containing compost and biochar for ornamental plant Dracaena deremensis. Pak. J. Agric. Sci. 2019, 56, 613-621.

15. García-Caparrós, P.; Llanderal, A.; Maksimovic, I.; Lao, M.T. Cascade cropping system with horticultural and ornamental plants under greenhouse conditions. Water 2018, 10, 125. [CrossRef]

16. García-Caparrós, P.; Llanderal, A.; El-Tarawy, A.; Maksimovic, I.; Lao, M.T. Crop and irrigation management systems under greenhouse conditions. Water 2018, 10, 62. [CrossRef]

17. Jiménez, R.M.; Caballero, M.R. El Cultivo Industrial de Plantas en Maceta; Ediciones De Horticultura S.L.: Reus, Spain, $1990 ;$ p. 664.

18. Csáky, A.G.; Martínez-Grau, M.A. Técnicas Experimentales en Síntesis Orgánica; Editorial Síntesis: Madrid, Spain, 1998.

19. García-Caparrós, P.; González-Salmerón, O.; Pérez-Saiz, M.; Calatrava, R.; Lao, M.T.; Chica, R.M.; De la Cruz, G. Types of shelter and covering materials influencing growth, pigment, and nutrient concentrations of baby rubber plants (Peperomia obtusifolia). HortScience 2018, 53, 1434-1440. [CrossRef]

20. García-Caparrós, P.; Llanderal, A.; Hegarat, E.; Jiménez-Lao, M.; Lao, M.T. Effects of exogenous application of osmotic adjustment substances on growth, pigment concentration, and physiological parameters of Dracaena sanderiana Sander under different levels of salinity. Agronomy 2020, 10, 125. [CrossRef]

21. Wellburn, A. The spectral determination of chlorophylls a and b, as well as total carotenoids, using various solvent with spectrophotometers of different resolution. J. Plant Physiol. 1994, 144, 307-313. [CrossRef]

22. García-Caparrós, P.; Llanderal, A.; Pestana, M.; Correia, P.J.; Lao, M.T. Tolerance mechanisms of three potted ornamental plants grown under moderate salinity. Sci. Hortic. 2016, 201, 84-91. [CrossRef]

23. García-Caparrós, P.; Llanderal, A.; Pestana, M.; Correia, P.J.; Lao, M.T. Lavandula multifida response to salinity: Growth, nutrient uptake, and physiological changes. J. Plant Nutr. Soil Sci. 2017, 180, 96-104. [CrossRef]

24. Ben Amor, N.; Ben Hamed, K.; Debez, A.; Grignon, C.; Abdelly, C. Physiological and antioxidant responses of the perennial halophyte Crithmum maritimum to salinity. Plant Sci. 2005, 168, 889-899. [CrossRef] 
25. Irigoyen, J.J.; Emerich, D.W.; Sánchez-Díaz, M. Water stress induced changes in concentrations of proline and total soluble sugars in nodulated alfalfa (Medicago sativa) plants. Physiol. Plant. 1992, 84, 55-60. [CrossRef]

26. García-Caparrós, P.; Llanderal, A.; Lao, M.T. Water and nutrient uptake efficiency in containerized production of fern leaf lavender irrigated with saline water. HortTechnology 2016, 26, 742-747. [CrossRef]

27. García-Caparrós, P.; Llanderal, A.; Rodríguez, J.C.; Maksimovic, I.; Urrestarazu, M.; Lao, M.T. Rosemary growth and nutrient balance: Leachate fertigation with leachates versus conventional fertigation. Sci. Hortic. 2018, 242, 62-68. [CrossRef]

28. Hogue, E.; Wilcow, G.E.; Cantliffe, D.J. Effect of soil P on phosphate fraction in tomato leaves. J. Am. Soc. Hort. Sci. 1970, 95, 174-176.

29. Krom, M.D. Spectrophotometric determination of ammonia: Study of a modified Berthelot reaction using salicylate and dicholoroisocyanurate. Analyst 1980, 105, 305-316. [CrossRef]

30. Lachica, M.; Aguilar, A.; Yanez, J. Análisis foliar: Métodos utilizados en la Estación Experimental del Zaidín. Anal. Edafol. Agrobiol. 1973, 32, 1033-1047.

31. Sonneveld, C.; van den Ende, J.; van Dijk, P.A. Analysis of a growing media by means of a 1:1 $\frac{1}{2}$ volume extract. Commun. Soil Sci. Plant Anal. 1974, 5, 183-202. [CrossRef]

32. Mengel, K.; Kirkby, E.A. Principles of Plant Nutrition; Kluwer Academic Publishers: Dordrecht, The Netherlands, $2001 ;$ p. 849.

33. Smesrud, J.K.; Duvendack, G.D.; Obereiner, J.M.; Jordahl, J.L.; Madison, M.F. Practical salinity management for leachate irrigation to poplar trees. Int. J. Phyto. 2012, 14, 26-46. [CrossRef]

34. Massa, D.; Incrocci, L.; Maggini, R.; Carmassi, G.; Campiotti, C.A.; Pardossi, A. Strategies to decrease water drainage and nitrate emission from soilless cultures of greenhouse tomato. Agric. Water Manag. 2010, 97, 971-980. [CrossRef]

35. Hawkesford, M.J.; De Kok, L.J. Managing sulphur metabolism in plants. Plant Cell Environ. 2006, 29, 382-395. [CrossRef]

36. Bhattarai, S.P.; Huber, S.; Midmore, D.J. Aerated subsurface irrigation water gives growth and yield benefits to zucchini, vegetable soybean and cotton in heavy clay soil. Ann. Appl. Biol. 2004, 144, 285-298. [CrossRef]

37. Pendergast, L.; Bhattarai, S.P.; Midmore, D.J. Benefits of oxygation of subsurface drip-irrigation water for cotton in a Vertosol. Crop Pasture Sci. 2014, 64, 1171-1181. [CrossRef]

38. Joo, J.H.; Bae, Y.S.; Lee, J.S. Role of auxin-induced reactive oxygen species in root gravitropism. Plant Physiol. 2001, 126, 1055-1060 [CrossRef] [PubMed]

39. García-Caparrós, P.; Llanderal, A.; El-Tarawy, A.; Majsztrik, J.; Lao, M.T. Response of container-grown confetti tree irrigated with runoff water. HortTechnology 2017, 27, 625-630. [CrossRef]

40. Santos, C.V. Regulation of chlorophyll biosynthesis and degradation by salt stress in sunflower leaves. Sci. Hortic. 2004, 103, 93-99. [CrossRef]

41. Li, Y.; Jia, Z.; Niu, W.; Zhang, M. Effect of post-infiltration soil aeration at different growth stages on growth and fruit quality of drip-irrigated potted tomato plants (Solanum lycopersicum). PLoS ONE 2015, 10, e0143322. [CrossRef]

42. Zhao, F.; Sun, J.; Jiang, Y.; Hu, D.; Yang, X.; Dong, M.; Yu, K.; Yu, S. Effect of rhizosphere aeration by subsurface drip irrigation with tanks on the growth of 'red globe' grape seedling and its absorption, distribution and utilization of urea-15 n. Sci. Hortic. 2018, 236, 207-213. [CrossRef]

43. Hameed, A.; Shafqat, F.; Nayyer, I.; Rubina, A. Influence of exogenous application of hydrogen peroxide on root and seedling growth on wheat (Triticum aestivum L.). Int. J. Agric. Biol. 2004, 6, 366-369.

44. Gil, P.M.M.; Ferreyra, R.E.; Barrerea, C.M.; Zúñiga, C.E.; Gurovich, L.R. Effect of injecting hydrogen peroxide into heavy clay loam soil on plant water status, net $\mathrm{CO}_{2}$ assimilation, biomass and vascular anatomy of avocado trees. Chil. J. Agric. Res. 2009, 69, 97-106. [CrossRef]

45. Szabados, L.; Savoure, A. Proline: A multifunctional amino acid. Trends Plant Sci. 2010, 15, 89-97. [CrossRef]

46. Lima, R.E.; Luciana, F.D.L.; Ferreira, J.F.; Suarez, D.L.; Bezerra, M.A. Translocation of photoassimilates in melon vines and fruits under salinity using ${ }^{13} \mathrm{C}$ isotope. Sci. Hortic. 2020, 274, 109659. [CrossRef]

47. Ristvey, A.G.; Lea-Cox, J.D.; Ross, D.S. Nitrogen and phosphorus uptake efficiency and partitioning of container-grown azalea during spring growth. J. Am. Soc. Hortic. Sci. 2007, 132, 563-571. [CrossRef]

48. Marconi, D.J.; Nelson, P.V. Leaching of applied phosphorus in container media. Sci. Hortic. 1984, 22, 275-285. [CrossRef] 